\title{
CHANGES IN THE MINERAL STATUS IN THE ORGANISMS OF YOUNG ATHLETES WITHIN A ONE-YEAR TRAINING CYCLE
}

\author{
Tatiana Krupskaja ${ }^{1}$, Ludmila Loseva ${ }^{1}$, Marija Pushkareva ${ }^{1}$, \\ Olga Tsivunchyk ${ }^{1}$, Slavamir Anufrik ${ }^{1}$, Kazys Milasius ${ }^{2}$, Marija Pečiukoniené ${ }^{2}$ \\ Yanka Kupala State University of Grodno ${ }^{1}$, Grodno, Belarus \\ Lithuanian University of Educational Sciences'2, Vilnius, Lithuania
}

\begin{abstract}
Background. Concentration of trace elements in the hair allows to get an idea how they are taken by the organism over a long period of time and to study relative correlations with different genetic, dietary and environmental factors. Research aim was to identify changes in the macro- and microelement status for young athletes involved in different sports activities depending on the preparation period within one-year training cycle.

Methods. A total of 78 young athletes aged 12-17 years, 32 of which were swimmers (group I), 17 - tennis players (group II) and 29 - Taekwondo athletes (group III) participated in the study. Biological material (hair samples), the volume of $0.1-0.15 \mathrm{~g}$ were taken for experimental studies in three periods of time: preparatory, competitive and transition period within a one-year training cycle. Hair samples were analyzed using the method of X-ray fluorescence (XRF) in order to detect multiple elements. For quantitative analysis, 8 chemical elements (sulfur, potassium, calcium, iron, copper, zinc, strontium and selenium) were determined in a single hair sample.

Results and conclusion. A non-invasive method to determine mass fraction of the chemical elements (sulfur, potassium, calcium, iron, copper, zinc, lead, chlorine, bromine, strontium, selenium) in a hair sample is an informative method for assessing the physiological response of the body (young athletes) with physical activity at different stages of training. The statistical analysis of the obtained results revealed the dependence of the concentration of trace elements from a kind of sports activity and stage of preparation for young athletes.
\end{abstract}

Keywords: chemical elements, X-ray fluorescence analysis, young athletes, preparation stage.

\section{INTRODUCTION}

I

n today's training and competition requirements to the major functional systems of the body of an athlete are extremely high, which can lead to a deep depletion of its functional reserves. Thus, the role of the various tools helping high performance and ensuring efficiency in adaptive processes sharply increased (Jeukendrup \& Gleeson, 2010). Sufficient concentration of minerals and trace elements is an important factor for increasing the athlete's performance, efficiency of training and recovery (Benardot, 2000; Wolf \& Manore, 2007). Obviously, non-balanced nutrition leads to the certain insufficiency of substances and trace elements along with extremely high physical activities. A matter of fact is that the trace elements are an essential part of many enzyme complexes, hormones and vitamins. Thus, the functioning of almost all regulatory systems of the body depends on the balance of trace elements (Hunt \& Groff, 1990; Maughan, 1999). Low concentrations of minerals and electrolytes are involved in the formation of the cytoskeleton of cells; they circulate in enzyme complexes and substances which are responsible for the supply of oxygen. They have a strong influence on the ion balance adjusting the sensitivity of nerve and muscle cells to maintain 
the acid-base balance of the organism (Clarkson, 1991, 2000). This all is an essential addition to the solid system of training contributing to more rapid and effective solutions, which, undoubtedly, stimulate and increase sportsmanship (Manore \& Thomson, 2000).

Thus, the most important point for a young athlete is to make a right choice of sports activity. There are various methods to determine the most appropriate sports activities, such as rapid tests and techniques, monitoring of functional state of the body, methodology of pedagogical testing, assessment of general physical development, screening of psychosomatic parameters during physical education, etc. It is necessary to maintain a daily balance of vitamins, macro-andmicroelements in the human body. These substances are involved in the processes of regulation of metabolism and play a significant role in the processes of adaptation to physical stress (Close et al., 2006; Олейник, Гунина, \& Сейфулла, 2010). In the recent years, hair sample analysis became wide popular along with the study of blood, plasma and urine in order to determine concentrations of macro- and microelements (Contiero \& Folin, 1994; Gordon, 1985; Kuangfei et al., 1999; Paschal, Di Pietro, Philips, \& Gunter, 1989). Concentration of the trace elements in the hair shows how they accumulated them in an organism within a long period of time and describes correlations between various factors, such as genetic, nutritional and environmental (Noguchi, Itai, Kawaguchi, Takahashi, \& Shinsuke, 2012; Pavlov, Agadzhanian, Alisievich, \& Chekhovskikh, 1989; Radomska, Graczyk, Konarski, \& Adamowicz, 1991). Nevertheless, concentrations of macro- and microelements in a hair sample depend on the age, sex and place of residence (Afridi, Kazi, Jamali, Kazi, \& Shar, 2006; Grabeklis, Lakarova, Eisazadeh, \& Skalny, 2011; Sturaro, Parvoli, Doretti, Allegri, \& Costa, 1994). Thus, the experimental data definitely show that the concentration of elements in the hair describes the status of all systems of the organism and a single hair sample is first of all, an integral indicator of the mineral status. Furthermore, there is not enough information about the mineral status for young athletes of different sex and age, involved in different sports at various stages of training within a one-year cycle. This study aimed to find solutions to the above mentioned challenges. Purpose of the study was to identify changes in macro- and microelement status for young athletes involved in different sports, depending on the period of training within a one-year training cycle.

\section{METHODS}

Research participants were 3 groups of young athletes (swimming, tennis and taekwondo) aged 12-17 years. A total of 78 young athletes aged 12 17 years, 32 of which were swimmers (group I), 17 - tennis players (group II) and 29 - Taekwondo athletes (group III). The athletes who participated in the study had chosen sport as a main subject in the educational and sports facilities in Minsk with specific training programs for each sports activity. The selection of the biological material hair samples, the volume of $0.1-0.15 \mathrm{~g}$ were taken in three periods of a one-year training process - in the preparatory, competitive and transition period. Hair multi-element analysis was done by using the method of X-ray fluorescence (XRF), shown in Figure. A single hair sample was used for the quantitative analysis of the concentration of 8 chemical elements (sulfur, potassium, calcium, iron, copper, zinc, strontium and selenium). Obtained results were compared with the references of chemical and biological samples and the average (interquartile range), described by various scientists in population-based studies (Hops, 1977; Qian, Chiao, Wu, \& Tian, 1990).

Advantages of the XRF method:

- possible to obtain spectrum review of all elements in one dimension;

- quick information;

- minimum sample preparation without destroying a sample;

- possible to study a samples on different matrices;

- low energy consumption and chemical reagents;

- affordable with low cost of sample analysis.

The obtained data was processed by methods of mathematical statistics. The results of the average $(\mathrm{X})$ described for all parameters in the different groups along with the standard deviation (S). Reliability in differences of element balance in the body of young athletes in different training periods was determined by the $t$-test (Student's $t$-test). Pearsons' correlation analysis of macroand microelements interrelations was carried out. "Statistica 7.0" program was used for statistical data processing. 
Figure. XRF method. Stages of sample preparation

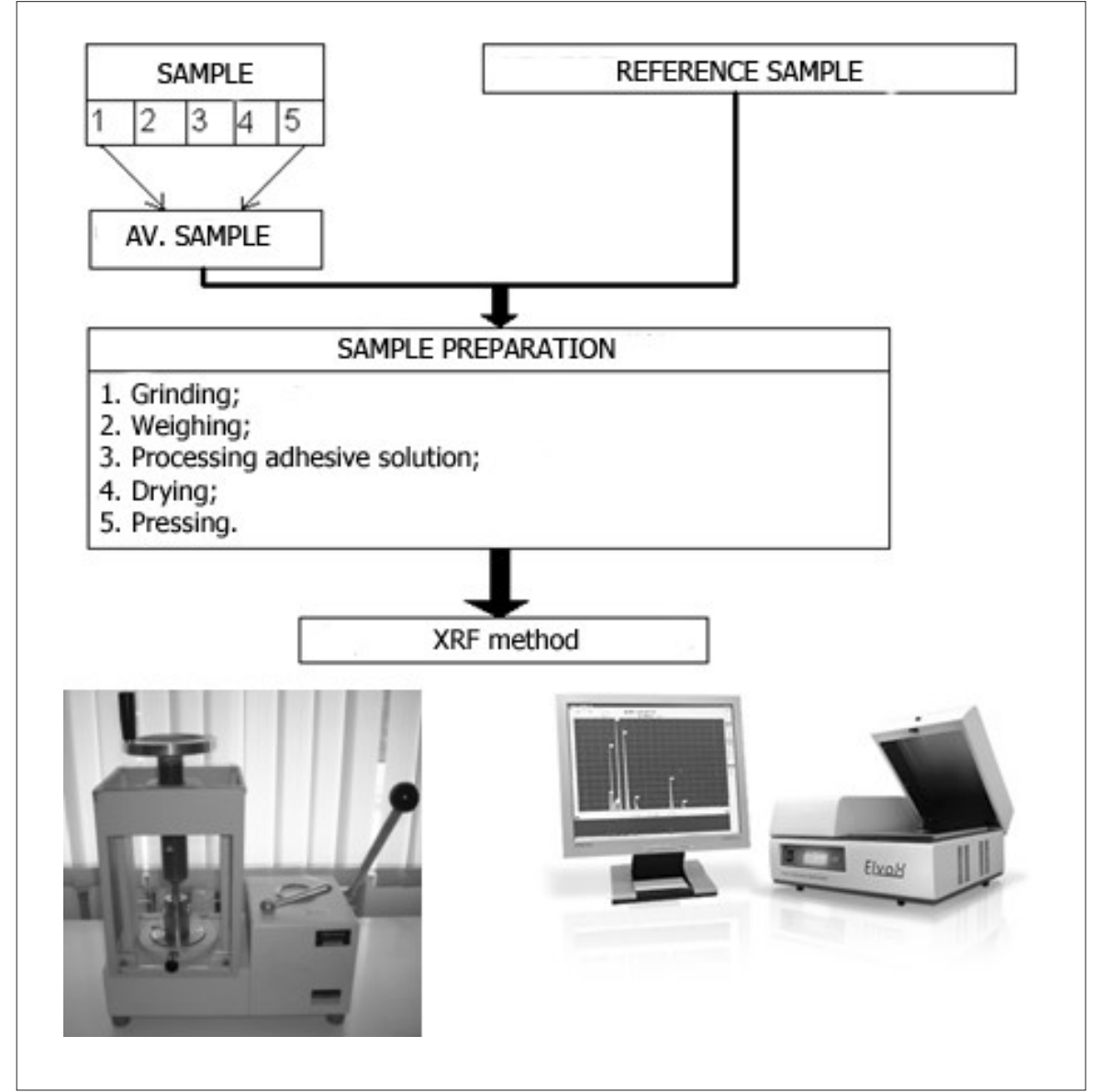

\section{RESULTS}

Studies of macro- and microelements in the hair of young athletes from different sports showed the changes of elemental balance depending on the stage of preparation (Table). The accuracy of the identified differences in the average of trace elements on the 1st and 2nd stages of preparation in a group of young swimmers was increased for $\mathrm{Ca}, \mathrm{Cu}$, Se (significance level of $p<.001$ ), while $\mathrm{K}$ and $\mathrm{Fe}$ dropped at the same level of reliability. Also, $\mathrm{Zn}, \mathrm{S}$ and $\mathrm{Sr}$ remained unchanged. The third phase of the study showed an increase of $\mathrm{Ca}, \mathrm{Cu}$ and $\mathrm{Se}$ compared to the first stage of the study as well as Fe compared to the second stage. In the transition period $\mathrm{K}, \mathrm{Zn}, \mathrm{Fe}$ and $\mathrm{Sr}$ was lower than in the preparation period. $\mathrm{Ca}$ did not increase significantly in the hair of young tennis players during a yearly training $(p>.05)$ while, $\mathrm{S}$ and $\mathrm{Sr}$ showed significant changes $(p<.001)$. Concentration of $\mathrm{K}, \mathrm{Cu}$ and $\mathrm{Fe}$ was down to the lower level $(p<.05)$. Concentration of $\mathrm{Ca}$ was detected as significant increasing the dynamics for taekwondo athletes in the competition; however, in the transitional period the level of this element was the lowest $(p<.001)$. The lowest concentration of $\mathrm{K}, \mathrm{Cu}, \mathrm{Fe}$ and $\mathrm{S}$ was detected in the competition period. All changes were considered statistically significant. Concentration of $\mathrm{Zn}$ was the highest in the competitive period. Concentration of $\mathrm{S}$ and $\mathrm{Sr}$ was the lowest in the transition period.

Correlations analysis between micro elements for children in different kinds of sports showed certain regularity. Only one correlation (straight average) between the iron and potassium was found for swimmers. For children who play tennis, strontium and selenium correlated with sulfur and zinc correlated with potassium and calcium accordingly. Correlation with potassium was showed as the opposite while with calciumdirectly. Such with increasing zinc, concentration of potassium decreased but concentration of calcium increased. Even more correlation highlights found for taekwondo athletes. Sulfur negatively correlated with potassium, calcium, selenium, iron and strontium as: $r=.63, r=.68$ and $r=.74$, accordingly. 
Table. Changes in concentration of macro - and microelements in hair samples of young athletes within one-year training cycle $(\mathrm{X} \pm \mathrm{S})$

\begin{tabular}{|c|c|c|c|c|c|c|c|c|c|}
\hline Sports & $\begin{array}{l}\text { Periods of } \\
\text { training }\end{array}$ & $\mathbf{C a}$ & $\mathbf{K}$ & Zn & $\mathrm{Cu}$ & $\mathrm{Fe}$ & $\mathbf{S}$ & $\mathrm{Se}$ & $\mathrm{Sr}$ \\
\hline \multicolumn{2}{|c|}{ Reference $\mu \mathrm{g} / \mathrm{g}$} & $550-1700$ & $70-170$ & $120-200$ & 9-30 & $10-30$ & $21000-49000$ & $0.3-1.2$ & $0-3$ \\
\hline \multirow{3}{*}{ 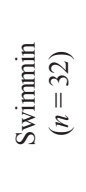 } & Preparatory & $1222.5 \pm 107.84$ & $184.00 \pm 17.46$ & $147.9 \pm 4.23$ & $7.6 \pm 0.55$ & $20.2 \pm 1.93$ & $35514.4 \pm 1639.06$ & $0.5 \pm 0.05$ & $4.6 \pm 0.47$ \\
\hline & Competitive & $1552.4 \pm 103.9$ & $77.4 \pm 9.34$ & $146.7 \pm 3.81$ & $9.7 \pm 0.55$ & $5.2 \pm 0.59$ & $35629.7 \pm 974.77$ & $1.2 \pm 0.45$ & $4.7 \pm 0.48$ \\
\hline & Transitory & $1329.9 \pm 73.44$ & $103.8 \pm 8.3$ & $139.00 \pm 3.55$ & $8.3 \pm 0.47$ & $10.6 \pm 2.15$ & $33271.1 \pm 1537.66$ & $0.6 \pm 0.07$ & $3.8 \pm 0.21$ \\
\hline \multirow{2}{*}{ 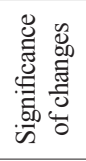 } & $\mathrm{t} \quad \mathrm{I}-\mathrm{II}$ & $\begin{array}{l}\mathrm{t}=16.7 \\
p<.001\end{array}$ & $\begin{array}{l}\mathrm{t}=11.8 \\
p<.001\end{array}$ & $\begin{array}{l}\mathrm{t}=1.6 \\
p>.05\end{array}$ & $\begin{array}{c}\mathrm{t}=4.3 \\
p<.001\end{array}$ & $\begin{array}{l}\mathrm{t}=38.4 \\
p<.001\end{array}$ & $\begin{array}{l}\mathrm{t}=0.5 \\
p>.05\end{array}$ & $\begin{array}{c}\mathrm{t}=4.2 \\
p<.001\end{array}$ & $\begin{array}{l}\mathrm{t}=1.8 \\
p>.05\end{array}$ \\
\hline & $\mathrm{t}$ I-III & $\begin{array}{c}\mathrm{t}=5.4 \\
p<.001\end{array}$ & $\begin{array}{c}\mathrm{t}=8 \\
p<.001\end{array}$ & $\begin{array}{l}\mathrm{t}=3.4 \\
p<.01\end{array}$ & $\begin{array}{l}\mathrm{t}=3.7 \\
p<.01\end{array}$ & $\begin{array}{l}\mathrm{t}=25.5 \\
p<.001\end{array}$ & $\begin{array}{l}\mathrm{t}=1.6 \\
p>.05\end{array}$ & $\begin{array}{l}\mathrm{t}=1.4 \\
p>.05\end{array}$ & $\begin{array}{l}\mathrm{t}=2.3 \\
p<.05\end{array}$ \\
\hline \multirow{3}{*}{ 員 } & Preparatory & $542.6 \pm 85.22$ & $293.5 \pm 58.27$ & $108.3 \pm 6.18$ & $7.9 \pm 0.42$ & $21.3 \pm 2.28$ & $34328.4 \pm 3179.11$ & $0.7 \pm 0.06$ & $3.9 \pm 0.41$ \\
\hline & Competitive & $536.7 \pm 68.04$ & $271.9 \pm 64.74$ & $104.3 \pm 6.24$ & $8.0 \pm 0.53$ & $9.07 \pm 1.25$ & $39558.9 \pm 3206.40$ & $0.7 \pm 0.08$ & $6.0 \pm 0.55$ \\
\hline & Transitory & $549.1 \pm 72.96$ & $258.3 \pm 62.86$ & $104.4 \pm 7.05$ & $7.3 \pm 0.44$ & $11.4 \pm 2.05$ & $36518.0 \pm 1583.04$ & $0.6 \pm 0.06$ & $4.5 \pm 0.49$ \\
\hline \multirow{2}{*}{ 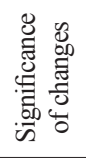 } & $\mathrm{t} \quad \mathrm{I}-\mathrm{II}$ & $\begin{array}{l}\mathrm{t}=1.3 \\
p>.05\end{array}$ & $\begin{array}{l}\mathrm{t}=0.2 \\
p>.05\end{array}$ & $\begin{array}{l}\mathrm{t}=1.6 \\
p>.05\end{array}$ & $\begin{array}{l}\mathrm{t}=1.5 \\
p>.05\end{array}$ & $\begin{array}{l}\mathrm{t}=27.5 \\
p<.001\end{array}$ & $\begin{array}{l}\mathrm{t}=14.1 \\
p<.001\end{array}$ & $\begin{array}{l}\mathrm{t}=1.0 \\
p>.05\end{array}$ & $\begin{array}{l}\mathrm{t}=35.5 \\
p<.001\end{array}$ \\
\hline & t I-III & $\begin{array}{l}\mathrm{t}=0.2 \\
p>.05\end{array}$ & $\begin{array}{l}\mathrm{t}=2.6 \\
p<.05\end{array}$ & $\begin{array}{l}\mathrm{t}=1.7 \\
p>.05\end{array}$ & $\begin{array}{l}\mathrm{t}=2.5 \\
p<.05\end{array}$ & $\begin{array}{l}\mathrm{t}=14.9 \\
p<.001\end{array}$ & $\begin{array}{l}\mathrm{t}=3.1 \\
p<.01\end{array}$ & $\begin{array}{l}\mathrm{t}=2.7 \\
p<.05\end{array}$ & $\begin{array}{l}\mathrm{t}=13.2 \\
p<.001\end{array}$ \\
\hline \multirow{3}{*}{ 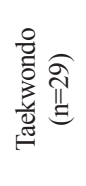 } & Preparatory & $585.0 \pm 112.02$ & $274.00 \pm 39.33$ & $138.2 \pm 9.95$ & $8.2 \pm 0.40$ & $24.6 \pm 2.28$ & $37233.4 \pm 2757.97$ & $0.6 \pm 0.06$ & $3.7 \pm 0.42$ \\
\hline & Competitive & $616.4 \pm 146.24$ & $126.5 \pm 23.06$ & $155.3 \pm 22.68$ & $7.1 \pm 0.47$ & $10.1 \pm 0.50$ & $29148.6 \pm 1121.24$ & $0.5 \pm 0.03$ & $2.7 \pm 0.32$ \\
\hline & Transitory & $394.9 \pm 42.6$ & $251.8 \pm 36.65$ & $114.5 \pm 6.41$ & $7.3 \pm 0.44$ & $13.3 \pm 1.86$ & $31462.4 \pm 1486.36$ & $0.4 \pm 0.04$ & $2.6 \pm 0.24$ \\
\hline \multirow{2}{*}{ 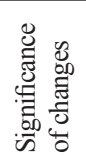 } & $\mathrm{t} \quad \mathrm{I}-\mathrm{II}$ & $\begin{array}{l}\mathrm{t}=2.1 \\
p<.05\end{array}$ & $\begin{array}{l}\mathrm{t}=26.4 \\
p<.001\end{array}$ & $\begin{array}{l}\mathrm{t}=3.1 \\
p<.01\end{array}$ & $\begin{array}{l}\mathrm{t}=13.5 \\
p<.001\end{array}$ & $\begin{array}{l}\mathrm{t}=20.9 \\
p<.001\end{array}$ & $\begin{array}{l}\mathrm{t}=12.1 \\
p<.001\end{array}$ & $\begin{array}{c}\mathrm{t}=4.6 \\
p<.001\end{array}$ & $\begin{array}{l}\mathrm{t}=14.9 \\
p<.001\end{array}$ \\
\hline & t I-III & $\begin{array}{c}\mathrm{t}=6.5 \\
p<.001\end{array}$ & $\begin{array}{l}\mathrm{t}=0.7 \\
p>.05\end{array}$ & $\begin{array}{c}\mathrm{t}=4 \\
p<.001\end{array}$ & $\begin{array}{c}\mathrm{t}=11.0 \\
p<.001\end{array}$ & $\begin{array}{l}\mathrm{t}=13.7 \\
p<.001\end{array}$ & $\begin{array}{l}\mathrm{t}=11.4 \\
p<.001\end{array}$ & $\begin{array}{c}\mathrm{t}=5.2 \\
p<.001\end{array}$ & $\begin{array}{l}\mathrm{t}=18.8 \\
p<.001\end{array}$ \\
\hline
\end{tabular}

\section{DISCUSSION}

Calcium is one of the major macro elements. It plays an essential role in bone formation, muscle contraction and mediated neuronal processes; $\mathrm{Ca}$ is important for blood clotting and ATP degradation, it regulates the activity of different enzymes. $\mathrm{Ca}$ deficiency leads to osteoporosis and weak muscle contraction. Thus, the lack of $\mathrm{Ca}$ must be constantly replenished. Paschal et al. (1989) found out that children and teenagers aged $12-14$ years had the highest need of calcium. Similar data were obtained by Kozielec, Drybańska-Kalita, Hornowska, and Sałacka (1996) who studied the needs of trace elements for inhabitants of the north of Poland. Our study showed that swimmers had significantly greater concentration of this element in the hair. Potassium is involved in nerve impulse transmission; it supports homeostasis and regulates muscle tonus. Lubkowska (2009) discovered a significant difference of this element in the hair of the Polish students different for women and men. In our study, the highest concentration of potassium (above the reference level) was detected in the hair of tennis and taekwondo athletes. Zinc is a part of enzymes, also involved in the metabolic processes in the synthesis of proteins and nucleic acids. It is a hematopoietic element. Długaszek, Skrzeczanowski, and Kaszczuk (2014) noted that concentration of this element should be higher in the hair of women. Contiero and Folin (1994) concluded that a higher concentration of zinc in the body helps to increase body weight and muscles for athletes. Our research has shown that concentration of Zinc was higher in the hair of young swimmers compared to other athletes. Copper determines growth and hemopoietic processes along with degradation of glycogen and glucose; it enhances lipolysis activity and accelerates the absorption of iron and hemoglobin synthesis. González-Reimers 
et al. (2014) showed that the concentration of $\mathrm{Cu}$ in the body depended on the degree of fatigue. With more significant fatigue, concentration of $\mathrm{Cu}$ strongly decreases. Our research has shown that concentration of $\mathrm{Cu}$ was on the lower level of the reference standards for young athletes. Iron is an essential element in the body for oxygen transport and as an integral part of hemoglobin and myoglobin. While it is involved in immune responses, it plays an important role for growth, hematopoiesis and influences enzymatic activity. There are many factors that determine iron deficiency in the body of athletes. Our research has shown that in all our participants there was a lack of this element during the competition period. During the recovery period concentration of $\mathrm{Fe}$ increased but has not reached the level of the preparation period. Selenium is an opposite to the degeneration of the fibres, which causes a lack of vitamin E. According to Momcilovic, Moroviic, Prejac, Skalnaya, \& Ivicic (2006), deficiency of selenium has a negative influence on muscle activity. The results of our study showed that concentration of Se in the hair of swimmers was the most. Sulfur is part of the protein, amino acids and certain hormones involved in digestion processes. It is as integral part of insulin that helps to regulate blood sugar. Concentration of this element did not exceed the reference limits in all our studies. Strontium is very important for the bone formation, so its concentration is crucial in childhood and adolescence. In our studies the highest level (6.0 \pm $0.55 \mu \mathrm{g} / \mathrm{g}$ ) of strontium was detected in the hair of tennis players in the competitive period which significantly exceeded the reference limits.

\section{CONCLUSIONS}

Based on the results of different groups of young athletes in swimming, tennis and taekwondo in the preparatory, competitive and transition periods for a one-year training cycle, we can draw the following conclusions:

1. Roentgen-fluorescent (XRF) method is a high-specific and an informative tool to determine concentration of macro- and microelements in the hair of young athletes at the different stages of the preparation for the annual cycle. The statistical analysis of the obtained results for chemical elements in the hair of young athletes revealed the related correlation between concentration of the elements, sport activities, the preparation phase and the age. Results of our studies might be useful for optimizing the training process and the nutrition of young athletes.

2. It is shown that concentration of calcium and zinc was significantly higher in the hair of swimmers compared to other athletes. There was a significant decrease of iron in the competitive period for that group of athletes.

\section{REFERENCES}

Afridi, H. I., Kazi, T. G., Jamali, M. K., Kazi, G. H., \& Shar, G. Q. (2006). The status of trace and toxic elements in biological samples (scalp hair) of skindisease patients and normal subjects. Turkish Journal of Medical Sciences, 36(4), 223-230.

Benardot, D. (2000). Nutrition for serious athletes. USA: Human Kinetics.

Clarkson, P. (1991). Minerals: Exercise performance and supplementation in athletes. Journal of Sports Sciences, 9, 91-116.

Clarkson, P. (2000). Trace minerals. In R. Maughan (Ed.) Nutrition in Sport (pp. 339-355). Oxford: Blackwell Science.

Close G. L., Ashton T., Cable T., Doran D., Holloway C., McArdle F., \& MacLaren D.P. (2006). Ascorbic acid supplementation does not attenuate post-exercise muscle soreness following muscle-damaging exercise but may delay the recovery process. British Journal of Nutrition, 95(5), 976-981.
Contiero, E., \& Folin, M. (1994). Trace elements nutritional status, use of hair as a diagnostic tool. Biological Trace Element Research, 40(2), 151-159.

Długaszek, M., Skrzeczanowski, W., \& Kaszczuk, M. (2014). Age-related mineral status of females and males hair in human health risk assessment. Trace Elements and Electrolytes, 31(3), 131-140.

González-Reimers, E.. Martín-González, C., GalindoMartín, L., Aleman-Valls, R., González-Pérez, J., JorgeRipper, C., ... Quintero-Platt, G. (2014). Hair copper in normal individuals: relationship with body mass and dietary habits. Trace Elements and Electrolytes, 31(2), 67-72. doi: 10.5414/TEX01337

Gordon, G. F. (1985). Sex and age related differences in trace element concentrations in hair. Science of the Total Environment, 42, 133-147.

Grabeklis, A. R., Lakarova, E. V., Eisazadeh, S., \& Skalny, A. V. (2011). Sex dependent peculiarities of some important element ratios in hair of schoolchildren. 
Trace Elements and Electrolytes, 28(2), 88-90. doi: 10.5414/TEP28088

Hopps, H. C. (1977). The biologic bases for using hair and nail for analyses of trace elements. Science of the Total Environment, 7(1), 71-78

Hunt, S., \& Groff, J. (1990). Advanced nutrition and human metabolism. St. Paul Publishing Company.

Jeukendrup, A, \& Gleeson, M. (2010). Sport Nutrition: An Introduction to Energy Production and Performance ( $2^{\text {nd }}$ ed.). Champaign, IL.: Human Kinetics.

Kozielec, T., Drybańska-Kalita, A., Hornowska, I., \& Sałacka, A. (1996). Levels of calcium, magnesium, zinc, copper and iron in hair of children and adolescents. Polski Merkuriusz Lekarski: Organ Polskiego Towarzystwa Lekarskiego, 1(2), 150-154.

Kuangfei, L., Yaling, X., Xuefeng, L., Zuoli, W., Bukkens, S., Tommaseo, M., \& Paoletti, M. (1999). Metallic elements in hair as a biomarker of human exposure to environmental pollution: A preliminary investigation in Hubei province. Critical Reviews in Plant Sciences, 18(3), 417-428.

Lubkowska, A. (2009). Concentration of selected elements in hair of healthy individuals with increased physical activity. Trace Elements and Electrolytes, 26(4), 145-149. doi: 10.5414/TEP26145

Manore, M., \& Thompson, J. (2000). Sport nutrition for health and performance. Champaign IL: Human Kinetics.

Maughan, R. J. (1999). Role of micronutrients in sport and physical activity. British Medical Journal, 55(3), 683-690.

Momcilovic, B., Moroviic, J., Prejac, J., Skalnaya, M. G., \& Ivicic, N. (2008). Relationship of iodine, selenium and copper in the hair and whole blood of depressed human subjects. Trace Elements and Electrolytes, 25(4), 195-198.
Noguchi, T., Itai, T., Kawaguchi, M., Takahashi, S., \& Shinsuke, T. (2012). Applicability of human hair as a bioindicator for trace elements exposure. In Interdisciplinary Studies on Environmental Chemistry Environmental Pollution and Ecotoxicology. TERRAPUB. P. 73-77.

Paschal, D. C., Di Pietro, E. S., Philips, D. L., \& Gunter, F. W. (1989). Age dependence of metals in hair in selected U. S. populations. Environmental Research, 48(1), 17-28.

Pavlov, I. V., Agadzhanian, N. A., Alisievich, V. I., \& Chekhovskikh, M. M. (1989). Comparative study of the macro- and microelemental composition of the hair on the head in inhabitants of various regions. Human Physiology (in Russian), 15(1), 154-161.

Qian, Q., Chiao, Z., Wu, Y., \& Tian, J. (1990). Study of trace elements in hair of athletes by synchrotron radiation X-ray fluorescence analysis. Hejishu, 14(8), 493-496.

Radomska, K., Graczyk, A., Konarski, J., \& Adamowicz, B. (1991). Evaluation of macro- and microelement content in the human body determined by hair analysis (Ocena zawartości makro- i mikroelementów w organizmie ludzkim na podstawie analizy włosów). Polski Tygodnik Lekarski, 46(24-26), 461-463.

Sturaro, A., Parvoli, G., Doretti, L., Allegri, G., \& Costa C. (1994). The influence of color, age and sex on the content of zinc, copper, nickel, manganese, and lead in human hair. Biological Trace Element Research, 40(1), 1-8.

Woolf, K., \& Manore, M. (2007). Micronutrient important for exercise. In Nutrition and sport (pp. 119136). Edinburgh: Churchill Livingstone Elveser.

Олейник, С. А., Гунина, Л. М., \& Сейфулла, Р. Д. (2010). Фармакология спорта. Киев: Олимпийская литература.
Corresponding author Kazys Milašius Lithuanian University of Educational Sciences Studentu str. 39, LT-08106 Vilnius

Lithuania

E-mail kazys.milasius@leu.lt 